

\section{Shirkah}

Journal of Economics and Business

Vol. 3, No. 1, January-April 2018

ISSN: 2503-4235 (p); 2503-4243 (e)

\section{Editor in Chief}

Dwi Condro Triono

\section{Managing Editor}

Jasanta Peranginangin

\section{Editorial Boards}

Abdul Azim Islahi,

Islamic Economics Institute, King Abdulaziz University, Saudi Arabia

Abu Umar Faruq Ahmad,

UBD School of Business and Economics Universiti, Brunei Darussalam

Cedomir Nestorovic,

ESSEC Business School Asia Pacific, Singapore

Fitri Wulandari,

Faculty of Islamic Economics and Business, IAIN Surakarta, Indonesia Johan Fischer,

Department of Social Sciences and Business Roskilde Universitetscenter, Denmark Muhamed Zulkhibri,

Islamic Research and Training Institute, Islamic Development Bank, Saudi Arabia M. Kabir Hassan,

Department of Economics and Finance, University of New Orleans, United States Musa Asy'arie,

Faculty of Islamic Economics and Business, IAIN Surakarta, Indonesia

Nunung Nurul Hidayah,

Aston Business School, Aston University, Birmingham, United Kingdom

Saim Kayadibi,

Department of Economics, Kulliyyah of Economics and Management Science, International Islamic University Malaysia, Malaysia 
Shaikh M Ghazanfar,

Departement of Economics, University of Idaho, Russian Federation

Sigit S. Wibowo,

Department of Management, Faculty of Economics and Business, Universitas Indonesia, Indonesia

Vihang R. Errunza,

Desmarais Global Finance Research Centre, Desautels Faculty and Management, McGill University, Canada

\section{Assistant to Editor}

M. Endy Saputro

M. Zainal Anwar

Shirkah Journal of Economics and Business is a peer-reviewed journal published three times a year (January-April, May-August and September-December) by Faculty of Islamic Economics and Business, Institut Agama Islam Negeri (IAIN) Surakarta Central Java, Indonesia. The main objective of Shirkah is to offer an academic space of exchange ideas and initiate the increase number of qualified article produced by postgraduate students, practitioners and academicians.

\section{Editorial Office}

Ruang Jurnal Shirkah

Lantai Dasar, Sayap Barat, Fakultas Ekonomi dan Bisnis Islam, IAIN Surakarta

Jln. Pandawa No. 1, Kartasura, Sukoharjo, Jawa Tengah Kode Pos. 57168

Phone (+62271) 781516 Fax: (+62271)782336

E-mail: shirkahjournal@iainsurakarta.ac.id; shirkahiainsurakarta@gmail.com

Website: http://shirkah.or.id/ 


\section{Shirkah}

Journal of Economics and Business

Vol. 3, No. 1, January-April 2018

ISSN: 2503-4235 (p); 2503-4243 (e)

\section{Table of Contents}

\section{Articles}

Aqeel Akhtar

Fahad Ahmed Qureshi

Mubeen Butt

Laws of Collateral in Today's World in Islamic Perspective

Anton Bawono

Creative Economic Development of Pesantren

Dwi Umardani

Conventional Home Loan and Islamic Home Financing in

Comparative Perspective

Iha Haryani

Dian Riskarini

Tia Ichwani

Business Development Strategy Model of SMEs

through SWOT and EFE-IFE Analysis

Ika Yoga

Halal Emotional Attachment on Repurchase Intention

Anik

Iin Emy Prastiwi

Macro Economic Challenges and Third Party Funds of Islamic Commercial Banks in Indonesia 


\title{
Laws of Collateral in Today's World in Islamic Perspective
}

\author{
Aqeel Akhtar \\ Bank Alfalah Islamic Pakistan \\ aqeelakhtar601@gmail.com \\ Fahad Ahmed Qureshi \\ American School of Oriental Research, Boston University \\ muftifaqureshi@gmail.com \\ Mubeen Butt \\ School of Islamic Economics, Banking and Finance, Minhaj University, Lahore India \\ mubeen.but89@gmail.com
}

\begin{abstract}
Taking from Pakistan State Bank case, this article initially elaborates and critically discusses collateral (in conventional term) and Islamic collateral (rahn). In conventional banking, collateral traditionally refers to secured lending (also known as asset-based lending). Since possession is pre-requisite for binding of the contract, the charge can be registered in this regard to the regulating authority. Third party charge registration in this regard will not be entertained until the debtor scrutinizes it with registration. We argue that it is allowed for a creditor to take one asset as collateral from two debtors and this asset will be considered from both debtors as rahn. Since one single asset is considered from both debtors, the creditor may hold the asset until his whole debt would be paid off. Although this research happens in Pakistan, the case of collateral and rahn can be academic precedence in Islamic global world.
\end{abstract}

Keyword: collateral, rahn, Pakistan state-banking 


\section{Introduction}

Much has theoretically analyzed the effect of trust disagreements on asset prices and financial contracts. The central feature of this model situates in the case of the traders borrow through selling collateral contracts to lenders who do not share the same opinions. In particular, the lenders do not value the collateral as much as the borrowers do, which represents an endogenous borrowing constraint. It has been considered the effect of this constraint in the types of collateral contracts that are available for trade (Mohamed Imtiyaz, Kassim, \& Harun, 2017). Moreover, it has examined the law of mortgages in Tanzania following the enactment of new land laws, in particular the Land Act 1999 (Mwita \& Yan, 2011). In this study, the statutory regime introduced by the Land Act, among others, has examined what the Act sought to address, its weakness and achievement (Carneiro-Da-Cunha, et al, 2015).

Another case, Lariba mortgage financing, has been feasible in the United States conducting strategically to satisfy the laws of the sharia and those of the United States (Elkhatib \& Gaunaurd, 2012; Nayeem, Shiliwala, \& Shiliwala, 2009). The initial market for Lariba mortgage refers to that of the Lariba Puritans accumulated a sizeable down payment but is not able to afford the full price (Tomura, 2018). The market size has crudely estimated to be 7,500 households in the US (Centre, 2010). Involvement with the community on the grassroots level has provided the safest way to finance and put in effect the "know your client" rule. Long-term (15 or 30-year mortgages) may offer the buyer an easy monthly payment but it also indirectly enhances the clients going deeper in debt. It has the responsibility of the Lariba banker to rid people of debt in order to live free (Ahiadorme, Gyeke-Dako, \& Abor, 2018). The Lariba helps pay off the debt faster. It has the most suitable in the American mobile society that changes residences or refinances once every 5 to 8 years (Pardina, 
Rapti, \& Groom, 2008). Lariba mortgages and financing brings real life into the Community Reinvestment Act stipulated by the American banking regulations (Bausell, 1991).

Collateral simply defines a borrower gives to a creditor to guarantee repayment of a loan (Bian, Lin, \& Liu, 2018). This security may be in the form of a mortgage on real estate, physical property such as consumer goods and business inventories, stocks and bonds, negotiable instruments, bills of lading, or certain intangible properties such as patents and copyrights (Abdul, 2010). It has usually necessary to supply some kind of collateral in business transactions, especially when loans being made by banks or other financial institutions (Al-Salim, 2009). If the borrower should defaultthat is, fail to repay the loan on time-the creditor may sell the collateral to recover the monies due (Grewal \& Sharma, 1991). Banks must also be careful to lend the money to people and firms that are creditworthymeaning they will be able to repay the loans.

The diversity of cases regarding the collateral have initially stimulated the authors to have discussed the problem of collateral from an Islamic perspective. This article do reviews how the collateral actually looks like from the opinions of four famous madzab in Islam. This paper argues that although the four schools of thought have different opinions, but substantially collateral problems cannot be separated from the regional/ context regarding the law. In the ensuing section, the authors have discussed it further in the light of Hanafi, Maliki, Shafi'i and Hanbali, while it in turn have been followed discussing on contractual, debtor abstention, the contingent and rented property of rahn.

\section{Four Madzab on Rabn}

Imam Hanafi wrote, "To hold valuable thing enables to fulfill the obligation/right wholly or partially due to right like physical or 
constructive debts/liability" (Abidin \& Amin, 1992; Haidar, n.d.,). In the light of aforementioned definition, according to Hanafi School, it denotes that "to hold" means due to somehow reason; and whether grasped thing is valuable or not, or whether the reason of holding is due to debt or other than that. It may be said that the basic purpose of rahn is to ascertain debts to be paid back off. Furthermore, custodian of rahn can be lender or trusted third party. "Valuable" signifies any sort of thing that has worth but the exceptions are unpurified, impurity, contaminated with haram and usufruct. "Obligation/right" means the right is obligated or incurred due to financial debt not other than that. "Enable to fulfil" denotes that it can fulfil and pay off the liability. Any liability other than that like punishment of death, oath, right of preemption and all those liabilities which are nonfinancial are not allowed to be collateralized in sake of them. However, to fulfil someone's financial right has two types: physical fulfillment and constructive fulfillment (Adelino, Schoar, \& Severino, 2018).

Physical fulfillment is the fulfilment in which the foreclosure occurs (Abidin \& Amin, 1992); while constructive fulfilment refers to the fulfilment in which the collateral asset has demolished or destroyed in the custody of mortgagee of trusted third party (Haidar, n.d.). "Wholly or partially" is evident in the case of physical fulfilment of collateral asset would be sold out and its price would compensate the lender. There is a little bit of detail in constructive fulfilment. The collateral asset is more than or equal to the value of debt, in doing so in case of destruction/demolish of the asset is called wholly constructive fulfilment (Giambona, Mello, \& Riddiough, 2018). The collateral asset which less than the value of debt, in case of destruction/demolish of the asset in the custody of mortgagee or trusted third party, would be called partially constructive fulfilment (Abidin \& Amin, 1992). "Like debt/liability" implies collateral can be taken against only debts not substance that cannot be compensated except 
the condition that would become the constructive debt (to be described) (Abidin \& Amin, 1992).

"Physical or constructive" suggests that there are two types of debts in according to Hanafi's opinion. Debt payable inward and outward, meaning that any debt which is mandatory apparently and insidious is to be paid against the subject matter has been purchased by the buyer, outstanding debts and payable rent (Ahiadorme et al., 2018). Debt payable inward not outward, stating to price of the subject matter owned by other than seller, price of slaughtered animal and later found that it was already dead. Debt not payable at spot despite the cause of obligatory occurs, such as rahn, is kept in sake of rent prior to enjoy the usufruct of hired thing (Giambona et al., 2018). As described earlier, constructive debt occurs after demolishing of any value either from reciprocal or non-reciprocal. Snatched thing subject matter possessed via void transaction so it can be demanded against all of the above instances (Abidin \& Amin, 1992).

According to Imam Maliki, "To spend what is transacted/ having uncertainty by the one who is entitled for, for sake of surety due to payable debts."(Al-Kharashi, 1988). Comparing it to Imam Shafi'is, “To make any valuable thing, as surety to pay the debts off, can compensate borrower in case of any foreclosure (Al-Sharbini \& al-Khatib, 1995). While imam Hanbali wrote, "Rendering any valuable as assurance to pay off debts, for compensation in case of default of mortgagor" (Al-Sharbini \& al-Khatib, 1995). The Prophet Muhammad gave precedence on this case; as narrated by Aisha, she said that, once the Prophet purchased some edible things (barley) from a Jew on deferred payment and gave his armour (shield made of iron) to him as collateral (Bukhari, 1992). It deems that the deferred sale is permissible as the Apostle purchased on deferred basis. It is permissible to take collateral against any debt. It is also permitted to deal with nonMuslim as denoted in hadith although it is absolute that their sources of 
income are contaminated with haram sources. To collateralize arms and weapon at non-Muslim is also permitted (Giambona et al., 2018). However, arm, weapon, ammunition, any assistance and all other instruments which would be hazardous for Muslim has strictly been prohibited.

Anas, a companion of the Prophet, told that the Apostle said, "The charges will be borne by the one who takes benefit from the collateral camel and the expenses would be bear that drinks milk of halal mammals"(Bukhari, 1992). In the light of above hadith, it may some highlight points. It depicts that the borrower may use his collateral asset. All capital expenditures are borne by borrower. Only borrower is allowed to enjoy the benefits of collateral assets. In case of lender enjoys the benefits, it would be interest and has strictly prohibited. Said bin Musayab, in addition, said that the Prophet said, “... (to be précised) it is not allowed to abstain the borrower from attaining benefits of the collateral assets hold by lender, because the one who bears the loss has a ultimate right to enjoy the benefits of the same" (al-Shafi $i$, n.d.). Only owner of collateral is allowed to take benefit from rahn. Lender is not allowed to take any benefit from the same. In case of destruction of rahn, loss will be borne by owner the borrower. Whatever profit/increase in rahn is owned by borrower and the loss will be borne by him as well.

Jabir also told that the prophet Muhammad said, "Who will kill Kaab bin Malik as he teased the almighty Allah and His Prophet?" Muhammad bin Salma said, "I will do it," so he went to his villa (accompanied with his friends) and said to Kaab bin Malik that, "We want to keep some kind of collateral in your custody.” In response, Kaab said, “... but you keep your women in our custody." They said, "How is it possible, you are the most beautiful person in Arab." Kaab said, "Then keep your children in my custody." They said, how it is possible, thence everyone would curse us, and so we will keep some arm as collateral in your custody."Abu Hurairah 
added that the Prophet said that mortgagee can enjoy the benefit of rahn up to the proportion of expenses borne by mortgagee regarding to keep the rahn in its actual sense and essence. Mortgagee can take benefit up to the proportion of his expenditures incurred due to keep it in his custody and maintain its essence as it is (Tomura, 2018).

For Hanbali School, mortgagee may enjoy the benefit of rahn with or without consultation of mortgagor in case of expenditures incurred and borne by him. The majority of jurists are of opinion that it has strictly prohibited to enjoy the benefit of mortgaged ( $\mathrm{rahn}$ ). This hadith has against the analogy due to two reasons: usufruct enjoyment by mortgagee is rendered valid and instead of related to the price, rahn being guaranteed with related to expenditure incurred and borne by mortgagee. This hadith has also against the unanimous declaration as well as authentic hadiths one of them describes the non-permissibility of enjoying the usufruct of an asset without the permission of its owner. The collation among all hadiths may describe as while the mortgagor denies to borne expenditures of rahn regarding its looking after, the mortgagee will bear the expenditures and reimburse the amount up to his expenditures by taking benefit from rahn. Hence the amount borne by mortgagee will be reimbursed. Moreover, as bearing expenses of collateralized asset $(\mathrm{rahn})$ is the responsibility of mortgagor and the assurance of debt payment is the right of mortgagee, in doing so the expenditures can be borne by mortgagee and in return the benefit and usufruct up to his expenditure will be enjoyed by him as like the case of a wife whose husband doesn't give her nafqah she may take it without the consent of his husband as his agent.

\section{Contractual Parties of Rahn}

Borrower can be more than one that two borrower may collateralize one asset or more than one whether these assets are same in genre or not. 
In this scenario, the one who owned greater part of the asset will be lender and the shorter will be borrower (Punzi \& Rabitsch, 2018). It is permissible because to collateralize an un-owned property with the consent of actual owner is allowed (Cipriani, Fostel, \& Houser, 2018). Moreover, the debts against which collateral is going to be kept in the custody of lender by both parties are of different in nature, genre and classification or not (Ahiadorme et al., 2018). On the other hand, the causal effects are different or not, for example, one party's debt is due to purchase of a commodity whereas the other one is due to rental agreement.

Hanafi School argues that commonage (shuyu) in state of various collateral assets are in the possession of a borrower not in collateral assets and to be possessed by one's own is an evidence. The ownership and possession is for single entity and is like one asset is collateralized to single lender (Giambona et al., 2018). If the lenders are more than one, it is also a single entity like castigation/penalty imposed for more than one person and no commonage regarding individual (Hussain \& Ali, 2017). Moreover, the collateral asset is related to a single contract and purpose of collateral (to hold against the debt for assurance to pay it back) is also a single entity (Mohamed Imtiyaz et al., 2017). In doing so, two conditions must be fulfilled, single mode contract, two borrowers make their asset collateralize to one lender altogether. If there isn't a single contract then it is not permissible (Punzi \& Rabitsch, 2018). No partially collateral; it is not permissible to collateralize an asset by two borrowers ascribing that half of the asset is from one borrower and rest is from another (Niinimäki, 2018). In conclusion, commonage in collateralized asset will void the contract in according to Hanafi School.

Other three Schools define that majority of jurists allow commonage considering the partial as another contract (Al-Tanukhi, 1902; Rushd, 1993; Jurjani, 1878; al-Shāfi'ī, 1990; Al-Mawardi, 1994; Al-Sharbini \& 
al-Khatib, 1995; Al-Mardawi, 1957; Al-Bahwti, n.d.; Al-Bahuti, n.d.). Another point should be discussed that in a case when half of the debt has been paid, is it allowed to acquire redemption of half of the collateral asset as well as whether the whole asset would be collateralized against the rest of bedt till payment or the half collateralized asset is allowed to be redeemed. Majority of jurists (Al-Tanukhi, 1902; Rushd, 1993; Jurjani, 1878; al-Shāfíī, 1990; Al-Mawardi, 1994; Al-Sharbini \& al-Khatib, 1995; Al-Mardawi, 1957; Al-Bahwti, n.d.; Al-Bahuti, n.d.) allow redemption of the half portion and the other part will remain in the custody of lender till payment. The reason behind it as mentioned that commonage is allowed. So as is allowed at the time of execution same is allowed at the time of retirement/ completion provided to fulfil the following condition. If there are various creditors but the reason to become debtor is same: such as acquiring loan by two partners from two lenders, the aforementioned detail is allowed. If the reasons are different and loans were acquired in different contract then the aforementioned detail will not be allowed.

Hanafi School claims that it is not allowed the partial redemption in case of half payment of debts and the whole collateral assets will remain encumbered against the rest of debts whether those assets are divisible or non-divisible. The reason behind it is, according to Hanafi School, the whole transaction has been a single contract and to distinguish among them heralds the loss of lender/creditor. Moreover, as the discrimination has not been allowed at the time of execution of the contract the same is not allowed at the time of retirement by paying debts off partially (AlSarakhsi \& Ahmad, 1978; Kasani, n.d.; Al-Marghinani, 1990 Al-Hanafi, n.d.; Abidin \& Amin, 1992; Haidar, n.d.; Al-Sharbini \& al-Khatib, 1995; Al-Mardawi, 1957). In a case of various debtors, if a debtor who has paid his debt off and wants redemption, it is allowed provided to fulfil the condition that no loss or damage will be borne by creditor(s). If creditor(s) 
has to bear loss or any damage, the partially redemption will not permissible and the debtor who has paid his debt off, his allocation will be considered as trust in the custody of creditor(s).

\section{Debtor's Abstention and Termination of Rahn}

If rahn is conditional in the sale or lease contract and debtor denies collateralizing any asset, there is a difference of opinion. For majority of the jurists, it is neither allowed to compel debtor to collateralize asset to creditor nor is allowed to the third party. The reason behind it is, rahn is a non-commutative contract and there is no compulsion in this regard but the creditor has both option, whether to execute the contract or not. Furthermore, this option is conferred because the creditor was agreed to execute the contract on those conditions in which his/its debts would be secured but now, the debt is not secured and it is like discrepancy and the option is granted in case of any loss to be suffered by any of them (Haidar, n.d.; Al-Sharbini \& al-Khatib, 1995; al-Shāfíī, 1990; Al-Mawardi, 1994; Al-Mardawi, 1957). Maliki School argues, on the aforementioned scenario, one can compel debtor to collateralize the notorious asset identified at the time of execution of contract. If there is no identification of asset for collateral then the collateral must be able to fulfillment the requirement of serving of debts. In case of denial, the creditor will have the right to decline (Jurjani, 1878; Al-Hattab, 1992).

It has been described in the aforementioned detail that prior to the possession of creditor, the borrower has a right to redeem it whether it is with mutual consent or not. Disposition made by debtor: if a debtor (borrower) makes some dispositions with or without consent of creditor, such as sale of asset (Giambona et al., 2018), gift, charity or donation, giving as dower, conditioned divorce, prize, rental and another rahn. These all types of contract in which the asset would move out from the 
ownership of debtor will void rahn contract owing to be unable of debtor to fulfillment the possession of asset in the custody of creditor, according to majority of the jurists (Ahmed, Vveinhardt, \& Ahmad, 2016). The rahn contract will be void and other contract will be executed whether the agreement of lending money is contingent or not but the creditor has a right to accept or decline it.

For Maliki School, rahn contract is binding right after the execution of offer and acceptance and debtor will be compelled to fulfil the contract; while the debtor has sold out the asset without the consent of creditor. If the rahn contract was optional after sale contract execution, the sale contract will be valid and will the consideration be supposed to be rahn or not, there is difference of opinion in Maliki jurists. If the rahn contract was conditional that debtor must give his asset as rahn to the creditor in case of deferred sale or advancing loan, it will be segregated into two types. If rahn, which is conditional in transaction, but not identified like a deferred sale transaction is executed or lending a loan and after the transaction buyer or debtor sells the rahn. In this scenario, the consideration received by him will be considered as rahn. If the rahn asset is identified but prior to execution of this contract, seller sells the asset or lending the loan (Bian et al., 2018). In this scenario, sale contract will be valid and rahn contract will be void.

It is appropriate to mention that deferred sale or lending money contract is contingent with the condition that this contract must be accompanied with rahn and debtor sells the asset, the creditor, in this regard, can either accept or decline (Saleh \& Salsabila, 2018). Any one of both parties becomes insane, frenzy, dies or compelled due to stupidity prior to the possession of rahn, there are difference of opinion among the jurists (Mikail, Kasri, Elatrash, \& Adewale, 2018). 
For Hanafi School, the rahn contract would be void due to abovementioned circumstances. On the other hand, this sort of contracts is permissible and all permissible contracts become void amid these situations. However, the creditor may either accept or decline (Kasani, n.d.; Al-Marghinani, 1990; Abidin \& Amin, 1992; Haidar, n.d.). According to Shafi'i and Hanbali School, despite the above-mentioned detail, the rahn contract is valid although it is an optional contract but it becomes obligatory by making analogy on optional sale contract, whether the rahn contract was conditional or optional. Moreover, if debtor afflicts with one of the aforementioned circumstances, his caretaker or guardian will stand in place of him.

As a result, if these circumstances occur from the side of debtor, and there is a benefit in execution of sale contract, the contract will be executed or else the contract would be declined (Mikail, Kasri, Elatrash, \& Adewale, 2018). On the other hand, if these are form creditor's side, his guardian will be in place of him with the consent of debtor but without his consent, the debtor will not be compelled but creditor has both rights accept as well as decline provided that rahn contract would be obligatory (al-Shāfíî, 1990; Al-Sharbini \& al-Khatib, 1995; Qudamah, 1996); Al-Bahwti, n.d.; Al-Bahuti, n.d.). As far as the demise of one of the parties, their guardian would be in place of him but no compulsion on their heirs regarding execution of the contract and in case of refusal of debtor's successor, the creditor's successor has both options in a case the rahn contract was compulsory (Ahiadorme et al., 2018). Furthermore, there are various creditors other than that, the debtor's successor has no right to keep the asset as rahn due to intermingle with others' right in that asset except a case in which all other creditors agree to keep as rahn to that creditor. 
According to Maliki School (Al-Tanukhi, 1902; Rushd, 1993; Jurjani, 1878; Al-Hattab, 1992), the rahn contract will be terminated in all the aforementioned circumstances occurred on debtor prior to the possession of creditor, whereas, creditor will have both right in all of the scenarios. Banned due to default: if debtor becomes defaulter prior to taking possession of rahn by creditor and other creditors demand their debts to be paid off, the rahn contract would become void and there is no option for debtor to give delivery of rahn asset to the creditor because as identification of the creditor and the debtor, meanwhile, is not entitled to specify any one of his creditors for payment (Tomura, 2018). On the other hand, the creditor has right (other than Maliki School) either to accept it or decline if the rahn contract was contingent at the time of debt initiation. The Malaki School has an opinion as same as the aforementioned in both cases whether it is due to negligence of creditor in taking possession of the asset or not and whether it is conditional or not. Moreover, the rahn contract will be valid in case of default of creditor and being banned.

Demise of parties: if debtor dies prior to taking the possession of rahn by creditor, there is the inverse of opinion among four Schools. According to majority of the jurists, rahn contract will be void right after the death of debtor prior the possession of rahn by creditor and there will be no right of debtor, in his death's disease, to deliver rahn asset to creditor due to intermingle of his debt with other creditors' debts except having the consent of all other creditors (Niinimäki, 2018). However, the creditor will have both right either accept or execute that agreement on which the rahn was supposed to be taken or decline. On the other hand, the rahn contract will be valid even in case of default of creditor (Kasani, n.d.; Al-Marghinani, 1990; Abidin \& Amin, 1992; Haidar, n.d.). According to Shafi'i School, in the above mentioned scenario the rahn contract will be valid and the debtor has an authority to identify some creditors for payment (al-Shāfíī, 1990; Al-Mawardi, 1994). 
It has two scenarios on circumstances of rahn asset. Prior to the possession of rahn asset, if the asset becomes faulted, there is indifference of opinion among the jurists are as follow: According to majority of the jurists, the contract will not be void, however, the creditor has both right either to accept the agreement for which the rahn was supposed to keep or decline (Kasani, n.d.; Al-Marghinani, 1990; Abidin \& Amin, 1992; Haidar, n.d.; Qudamah, 1968; Al-Sharbini \& al-Khatib, 1995; Al-Mardawi, 1957; Al-Bahwti, n.d.; Al-Bahuti, n.d.). According to Shafi'i School, the contract would be void due to fault, however, the creditor has both right either to accept the agreement for which the rahn was supposed to keep or decline (al-Shāfi'i, 1990; Al-Mawardi, 1994). Destruction of rahn asset: the rahn contract would devoid due to the destruction of the asset in according to unanimous declaration of four Schools. In either cases-prior to possession or after-because after the possession the contract would be void and prior would be void especially (al-Shāfíī, 199; Al-Mawardi, 1994; Al-Mardawi, 1957; Al-Sharbini \& al-Khatib, 1995; Al-Bahwti, n.d.).

\section{Rabn of Debt and Rabn of Rented Hired}

It means that any debt, whether originated due to sale or purchase contract or advancing loan, is to be kept as rahn. It has two types as: rahn of debt on lender is to be kept by borrower against the debt of lender on borrower. For example: Mr. A (borrower) has to pay $\$ 100$ to $\mathrm{Mr}$. B (lender) and Mr. B has to give $100 \mathrm{~kg}$ of wheat to Mr. A. Mr. A keeps his debt (100kg of wheat) as rahn to B against the debt (payment of \$100) obligated on Mr. A to Mr. B. rahn of debt on third party is to be kept by borrower against the debt of lender on borrower. For example: : $\mathrm{Mr} \mathrm{A}$ (borrower) has to pay $\$ 100$ to $\mathrm{Mr} \mathrm{B}$ (lender) and $\mathrm{Mr} \mathrm{C}$ has to give $100 \mathrm{~kg}$ of wheat to $\mathrm{Mr}$ A. Mr A keeps his debt (100kg of wheat) which is obligated on $\mathrm{Mr} \mathrm{C}$ as rahn to $\mathrm{B}$ against the debt (payment of $\$ 100$ ) obligated on 
$\mathrm{Mr} \mathrm{A}$ to $\mathrm{Mr} \mathrm{B}$. In the light of aforementioned details, the four jurists are indifference of opinion.

According to majority of the jurists, both kind of rahn of debt is not allowed (Kasani, n.d.; Abidin \& Amin, 1992; Haidar, n.d.; al-Shāfi ī, 1990; Al-Mawardi, 1994; Al-Sharbini \& al-Khatib, 1995; Al-Bahwti, n.d.), because of the reasons that; a) The possession on this type of rahn is not possible; b) There is an ambiguity leads to dispute between the parties; c) It is just an evidence of right, obligated on another, that cannot be possessed; owing to aforementioned reasons, this sort of debt cannot be rahn. However, an exceptional case is there that if the debt is originated at the end of the contract, it can be rahn. For example, borrower sells his property which is encumbered as rahn with the prior consent of lender on the condition that whatever the consideration will be received in this regard would be considered as rahn.

According to Maliki, one citation of Shafi'i and Hanbali School, both kind of rahn is valid, because Maliki jurists validates the sale of debts so is the rahn and the debt is tantamount to goods (valuable specs). Moreover, according to Maliki jurists, the basic condition for validation of this sort of rahn of debt originated in the virtue of sale contract or other than sale, the maturity of rahn of debt is the same as against rahn of debt to be kept or more than it (Al-Tanukhi, 1902; Jurjani, 1878; AlHattab, 1992), otherwise the contract of this kind of rahn would be void. The reason is that, if the maturity is less than the maturity against which this rahn of debt being kept, it will originate advancing loan in case of debt originated due to borrowing and lending. On the other hand, it will originate the interminglement of debt and sale agreement and both kind of agreement are void agreement. Furthermore, the status of possession has been discussed earlier (Al-Tanukhi, 1902; Jurjani, 1878; Al-Hattab, 1992). 
If a rented or trusted property is kept as rahn by the owner to tenant or trustee or other then them, it is allowed with the difference of opinion as below. According to Hanafi School, if both parties agree with their mutual consent on rahn contract then the other contracts such as leasing or trust will be void as the congregation of two type of contract is not allowed (Kasani, n.d.; Abidin \& Amin, 1992; Haidar, n.d.). According to Maliki School, if the rahn is kept to other than lessee or trustee, it is allowed provided that lender must identify himself beyond any other entity and the tenant would become agent of lender regarding taking possession (Jurjani, 1878; Al-Hattab, 1992; Rushd, 1993). According to Shafi'i and Hanbali School, if rahn is kept to tenant or trustee, it will have both entities the tenant as well as the creditor (lender) and there is no contravention in compounding of being tenant and creditor in a single entity. If rahn is kept other than either (tenant or trustee) prior to the mutual consent of creditor, it is allowed, otherwise (without consent of creditor) if there is the consent of tenant the rental agreement would be void and without the consent of tenant would void the rahn contract.

As far as the trust deed concern, as this sort of agreement is nonbinding, so it will be void as the rahn contract executes. Moreover, as far as the possession is concerned, the possession of rahn befalls substitutionary under the possession of rental of trust in a case where the creditor and tenant or trustee is the same entity in according to majority of the jurists. However, according to Shafi'i School, a considerable span of time must past for the sake of valid possession. On the other hand, if the tenant or trustees are other than creditor, the same detail will apply as mentioned earlier. 


\section{Conclusion}

Rahn contract is executed after offer and acceptance, the one who initiates the contract is called offer and the other one who accepts it is called acceptance. Rahn contract is not binding any more until the possession kept by creditor, that means prior to possession this contract remains unbinding on both parties. Rahn contract is the contract which is executed for assurance and guarantee for the debt created or to be created on debtor. In case of unable to pay or default, the rahn asset would be sold out in the market and the price received against it would be compensated to creditor. Whatever is higher will be returned to debtor and on the other hand, in case of amount not to compensate wholly, the debtor will be accounted for. In case the rahn asset is borrowed to third party and debtor becomes defaulter, the market price of the asset, if sold and compensated to creditor, will be paid by debtor to third party.

Possession of asset means, creditor takes it in custody physically and all rights belonged to debtor will remain same except right to use and dispose of prior to the consent of creditor. Since possession is pre-requisite for binding of the contract, the charge can be registered in this regard to the regulating authority. Third party charge registration in this regard will not be entertained until the debtor scrutinizes it with registration. It is allowed for a creditor to take one asset as collateral ( $r a h n)$ from two debtors and this asset will be considered from both debtor as rahn. Since one single asset is considered from both debtors, the creditor may hold the asset until his whole debt would be paid off.

It is allowed for two creditors to hold one asset from one debtor who is payable to two parties and this asset will be representative from both debts. If an asset is kept as rahn to two creditors from one debtor, the whole asset will remain under pledged until the whole debt has been paid and half or its portion up to its payment, will not be redeemed if the half debt has been paid. In case of mortgage, all creditors would be compensated 
either on first ranking charge or joint pare-paso charge according to their charge registration. One creditor will register the charge and would be given a registration number and after that, it's all charges will be registered under the same given number. Acquisition of rahn asset can be more than its amount in a single contract and in case of more than one creditors, the same will be considered as rahn for all of the debts taken or initiated by various creditors.

In commonness of rahn, it is contingent that the asset which is supposed to be kept as rahn must have an ability of being subject matter in sale or purchase contract like existence, valuable, deliverable etc. so, what can be subject matter can be rahn as well. Moreover, since subject matter can be sold out besides having in the joint ownership of partners the same as in the case of rahn. In the domain of rahn, everything which is considered an integral part of asset will be included in the contract of rahn. If debt is collateralized as rahn, handing over the evidence of receivable will be considered as taking possession. Endorsement of debt as rahn is allowed subject to the written evidence as required by regulating authority. A periodical entitlement will be reserved for creditor regarding the rahn asset and all expenses related to its safety will be borne by creditor. 


\section{References}

Abdul, -Rahman, Y. (2010). The Art of Islamic Banking and Finance: Tools and Techniques for Community-Based Banking: Wiley.

Abdul-Rahman, Y. (2014). The Art of RF (Riba-Free) Islamic Banking and Finance: Tools and Techniques for Community-Based Banking: Wiley.

Abidin, I., \& Amin, M. (1992). Raddul Mukhtar Alad Durril Mukhtar. Beirut: Darul Fikr.

Adelino, M., Schoar, A., \& Severino, F. (2018). The role of housing and mortgage markets in the financial crisis. Annual Review of Financial Economics, 10, 25-41. https://doi.org/10.1146/annurevfinancial-110217-023036

Ahiadorme, J. W., Gyeke-Dako, A., \& Abor, J. Y. (2018). Debt holdings and investment cash flow sensitivity of listed firms. International Journal of Emerging Markets, 13(5), 943-958. https://doi.org/10.1108/ IJoEM-04-2017-0126

Ahmed, R. R., Vveinhardt, J., \& Ahmad, N. (2016). The impact of time and regime on external debts of Pakistan: An empirical study (pp. 486-497). Presented at the Proceedings of the 27th International Business Information Management Association Conference Innovation Management and Education Excellence Vision 2020: From Regional Development Sustainability to Global Economic Growth, IBIMA 2016. Retrieved from https://www.scopus.com/ inward/record.uri?eid=2-s2.0-84984601427\&partnerID=40\&md5= 1c1ec6e57e1b5f87efc52f1efd17290d

al-Shāfí̄i, A. M. (1990), al-Umm. Beirut: Dār Al-Kutub Al-’Ilmiyyah.

al-Shafi'i, M. bin I. (n.d.). Musnad al-Shafi 'i. Beirut: Dar al-Kutub al'Ilmiyyah, tt.

Al-Bahuti, M. bin Y. bin. (n.d.). Idris. Syarh Muntaha al-Iradat. Bayrut: Dar al-Fikr.

Al-Bahwti, M. bin Y. (n.d.). Kashf al-Qina"an Matn al-Iqna'. Dar Al-Fikr. 
Al-Hanafi, I. H. (n.d.). Fathul Qadir. Bairut, Darul Kutub.

Al-Hattab, M. (1992). Mawahib al-jalil fi sharh mukhtasar al-khalil. Damascus: Dar Al-Fikr.

Al-Kharashi, M. B. (1988). Sharh Mukhtasar Khalil. Damascus: Dar AlFikr.

Al-Mardawi, A. (1957). Al-Insaf. Beirut: Dar Ihya Al-Turath Al-Arabi.

Al-Marghinani, B. A. A. (1990), al-Hidaya. Beirut: Dar Al-Arqam.

Al-Mawardi, A. al-Hasan. (1994). al-Hawi al-Kabir (Vol. 7).

Al-Salim, F. H. (2009). Islamic Financial Product Innovation. International Journal of Islamic and Middle Eastern Finance and Management.

Al-Sarakhsi, S. al-Din, \& Ahmad, I. (1978). al-Mabsut. Cairo: Dar-alMa'rifah.

Usmani, MT (2007). Sukuk and their contemporary applications (Sheikh Yusuf Talal DeLorenzo, Trans.). Saudi Arabia: AAOIFI Shari'a Council Meeting.

Al-Sharbini, S. M. al-Khatib, \& al-Khatib, I. M. (1995). Mughni al-Muhtaj ila Marifah Maani Alfaz al-Minhaj. Beirut: Dar al-Fikr.

Al-Tanukhi, A.-I. S. bin. (1902). al-Mudawwanah al-Kubra. Beirut: Dar Al-Shadr.

Ariff, M., \& Iqbal, M. (2011). The Foundations of Islamic Banking: Theory, Practice and Education: Edward Elgar Publishing Limited.

Ariff, M., \& Studies, I. o. S. A. (1988). Islamic Banking in Southeast Asia: Islam and the Economic Development of Southeast Asia. Singapore: Institute of Southeast Asian Studies.

Bausell, R. B. (1991). Advanced Research Methodology: An Annotated Guide to Sources: Scarecrow Press.

Bian, X., Lin, Z., \& Liu, Y. (2018). House price, loan-to-value ratio and credit risk. Journal of Banking and Finance, 92, 1-12. https://doi. org/10.1016/j.jbankfin.2018.04.006

Bukhari, I. (1992). Shahih Bukhari (Vol. III). 
Carneiro-Da-Cunha, J. A., Dos Santos, M. G., De Souza, L. J., Alssabak, N. A. M., \& Macau, F. R. (2015). The history of an Islamic entrepreneurship: Achieving exporting-network leadership through religious legitimacy. International Journal of Business and Globalisation, 15(3), 272-293. https://doi.org/10.1504/IJBG.2015.071921

Centre, Q. F. (2010). Islamic Finance: Instruments and Markets: Bloomsbury Information Limited.

Cipriani, M., Fostel, A., \& Houser, D. (2018). Collateral Constraints and the Law of One Price: An Experiment. Journal of Finance, 73(6), 2757-2786. https://doi.org/10.1111/jofi.12722

Elkhatib, D. H., \& Gaunaurd, P. M. (2012). Islamic Finance. The International Lawyer, 46(1), 281-286.

Giambona, E., Mello, A. S., \& Riddiough, T. J. (2018). Real Assets, Collateral and the Limits of Debt Capacity. Real Estate Economics, 46(4), 836-886. https://doi.org/10.1111/1540-6229.12207

Grewal, D., \& Sharma. (1991). The Effect of Salesforce Behavior on Customer Satisfaction; An Interactive Framework,. Journal of Personal Selling \& Sales Management, 11(3).

Haidar, A. (n.d.). Durar Al-Hukam Syarh Majalah Al-Abkam. Dar AlKutub Al-'Ilmiyyah: Lebanon.

Hanif, M. (2011). Islamic Banking: Financial Reporting Perspective: CreateSpace Independent Publishing Platform.

Hussain, L., \& Ali, M. M. (2017). Sharīah non-compliant assets as rahn (pledge) in Islamic banking products: a fiqhī perspective. ISRA International Journal of Islamic Finance, 9(2), 196-199. https://doi. org/10.1108/IJIF-08-2017-0018

Jurjani, M. I. (1878). Zakheera-Khwarzam-Shahi. Munshi Nawal Kishore, Lucknow, 540.

Kasani, A. B. al. (n.d.). Badai' al-Shanai'fi Tartib al-Syarai'. Beirut: Dar AlKutub Al-Ilmiyah. 
Mikail, S. A., Kasri, N. S., Elatrash, S. R., \& Adewale, A. A. (2018). Framework for financial hardship indebtedness management in abandoned housing projects in Malaysia. ISRA International Journal of Islamic Finance, 10(1), 102-110. https://doi.org/10.1108/IJIF-032018-0027

Mohamed Imtiyaz, M. N., Kassim, S., \& Harun, N. Z. (2017). Perceived fairness in islamic home financing: Comparison between Al-Bay' Bithaman Ajil and Musharakah Mutanaqisah partnership contracts. Planning Malaysia, 15(4), 35-44.

Mwita, D., \& Yan, C. (2011). Re-positioning public and private resources in urban housing projects development the case of the city of Dar es Salaam, Tanzania (Vol. 1, pp. 694-699). Presented at the BMEI 2011 - Proceedings 2011 International Conference on Business Management and Electronic Information. https://doi.org/10.1109/ ICBMEI.2011.5917031

Niinimäki, J.-P. (2018). Collateral in credit rationing in markets with asymmetric information. Quarterly Review of Economics and Finance, 68, 97-102. https://doi.org/10.1016/j.qref.2017.10.001

Pardina, M. R., Rapti, R. S., \& Groom, E. (2008). Accounting for Infrastructure Regulation: An Introduction: World Bank.

Punzi, M. T., \& Rabitsch, K. (2018). Effectiveness of macroprudential policies under borrower heterogeneity. Journal of International Money and Finance, 85, 251-261. https://doi.org/10.1016/j. jimonfin.2017.11.008

Qudamah, I. (1968). al-Mughni li Ibn Qudamah. Kairo: Maktabah AlJumhuriyyah

Rushd, I. (1993). Bidayat al-Mujtahid, vol. 2. Beirut: Dar Al-Fikr.

Saleh, C., \& Salsabila, K. (2018). Success factors in Halal Marketing Mix. Journal of Engineering and Applied Sciences, 13, 5308-5312. https:// doi.org/10.3923/jeasci.2018.5308.5312 
Tomura, H. (2018). Payment instruments and collateral in the interbank payment system. Journal of Economic Theory, 178, 82-104. https:// doi.org/10.1016/j.jet.2018.08.008

Vogel, F. E., \& Hayes, S. L. (1998). Islamic Law and Finance: Religion, Risk, and Return: Springer Netherlands.

Vol. 3 No. 1, January - April 2018 
24 Aqeel Akhtar, Fahad Ahmed Qureshi, Mubeen Butt

Vol. 3 No. 1, January - April 2018 


\section{Shirkah Author Guidelines}

Shirkah currently offers two routes to submit manuscripts. We highly recommend to submit the articles which are made using OJS (Open Journal System). Feel free register as author soon through visiting http:// shirkah.or.id/index.php/home/user/register. The authors may directly send their manuscripts, along with their resume, to shirkahiainsurakarta@ gmail.com. Please prepare your manuscripts, using following guidelines:

1. Manuscript must be written in English. Submitted articles should not have been published or be under review for publication with another journal.

2. Manuscript's length is about $15-20$ pages, typed in one-half spaced on A4-paper size.

3. Manuscript must include an $150-200$ word abstract and keywords.

4. Manuscript must be arranged as follows: Title, Name of Author, E-mail address, Abstract, Keywords, Introduction (including method if any), Discussion, Conclusion, References.

5. Manuscript's titles not more than ten words.

6. Manuscript must be submitted in Microsoft Word or RTF.

7. Arabic words should be transliterated according to the style of International Journal of Middle Eastern Studies.

8. Manuscript references are preferably derived from the up-to-date references.

9. The author's resume should be submitted separately, consisting of at least full name, institutional address, phone number, areas of studies, and recent publications (if any).

10. Shirkab use APA Style 6th edition (2010) as reference format writing. We suggest the use of a reference manager software such as Mendeley, Zotero, and Endnote at templating the citation style. APA Style to be used is as follows: 


\section{Book with single author}

Swann, G. M. Peter. (2014). The Economics of Innovation an Introduction. Cheltenhum \& Northampton: Edward Elgar.

in-text citation: (Swann, 2014)

\section{Articles in reference books}

Alatas, S. F. (2006). Islam and the Science of Economics in Abu Rabi', I.M. The Blackwell Companion to Contemporary Islamic Thought. USA: Willey-Blackwell (pp. 587-606).

in text citation: (Alatas, 2006)

\section{E-Book}

Hackett, Rosalind (2007). "Religous Dimentions of War and Peace: Introduction.” Dalam Gerrie ter Haar dan Yoshio Tsuruoka (Ed.), Religion and Society: An Agenda for the 21st Century (h. 3-6). Retrieved from http:// brill.nl.

in text citation: (Hackett, 2006)

\section{Master's thesis, from a commercial database}

McNieI, D. S. (2006). Meaning through narrative: A personal narrative discussing growing up with an alcoholic mother (Master's thesis). Available from ProQuest Dissertations and Theses database. (UMI No. 1434728)

in text citation: (Mc Niel, 2006)

\section{Doctoral dissertation, from an institutional database}

Adams, R. J. (1973). Building a foundation for evaluation of instruction in higher education and continuing education (Doctoral dissertation). Retrieved from http://www.ohiolink.edu/etd/

in text citation: (Adams, 1973) 


\section{Doctoral dissertation, from the web}

Bruckman, A. (1997). MOOSE Crossing: Construction, community, and learning in a networked virtual world for kids (Doctoral dissertation, Massachusetts Institute of Technology). Retrieved from http:/www-static. cc.gatech.edu/--asb/thesis/

in text citation: (Bruckman, 1997)

\section{Journal article with No DOI}

Bourkhis, K., and Nabi, M. S. (2013). Islamic and conventional banks' soundness during the 2007-2008 financial crisis. Journal Metrics, 22(2), 68-77.

in-text citation: (Bourkhis \& Nabi, 2013).

\section{Journal article with DOI}

Ichwan, M. (2012). The Local Politics Of Orthodoxy: The Majelis Ulama Indonesia in the Post-New Order Banten. Journal Of Indonesian Islam, 6(1), 166-194. doi:http://dx.doi.org/10.15642/JIIS.2012.6.1.166-194

In text citation : (Ichwan, 2012)

\section{Abstract as citation}

Hasan, N. (2012). Islamist Party, Electoral Politics And Da'wah Mobilization Among Youth : The Prosperous Justice Party (PKS) in Indonesia. Journal of Indonesian Islam, 6(1), 17-47. Abstract from http:// jiis.uinsby.ac.id/index.php/jiis/article/view/97

in text citation : (Hasan, 2012)

\section{Mass media article}

Sahal, Akhmad (2014, March 2). Kiai Sahal dan Realisme Fikih.Tempo Magazine, p. 120.

in text citation : (Sahal, 2014) 


\section{Research report}

Fisher, B. S., Cullen, F. T., \& Turner, M. G. (2000). The Sexual Victimization of College Women. Research Report.

in text citation : (Fisher, Cullen, Turner, 2000)

\section{Monograph}

Routray, Bibhu Prasad (2013), National Security Decision-Making in India (RSIS Monograph No. 27). Singapura: Rajaratnam School of International Studies.

in text citation : (Routray, 2013)

\section{Proceeding article}

Sudibyakto, Hizbaron, D.R., \& Jati, R (Ed.) (2009), Proceeding International Seminar Disaster Theory, Research and Policy. International seminar held by Sekolah Pascasarjana, Universitas Gajahmada, Yogyakarta, 8-9 Desember 2009.

in text citation : (sudibyakto and Jati, 2009)

\section{Paper conference/seminar/symposium}

Janutama, Herman Sinung (2011). "Kraton dan Hubungan Antar Agama." Paper presented in Seminar Kraton dan Panatagama held by Center for the Study of Islam and Social Transformation (CISForm), Yogyakarta, 17 November.

in text citation :(Janutama, 2011)

\section{Online article in web}

Shiva, (2006, February). Bioethics: A Third World Issue. Native-web. Diperoleh dari http://www.nativeweb.org/ pages/legal/shiva.html

in text citation : (Shiva, 2006) 


\section{Online research report}

Kessy, S. S. A., \& Urio, F M. (2006). The contribution of microfinance institutions to poverty reduction in Tanzania (Research Report No. 06.3). Retrieved from Research on Poverty Alleviation website: http://www. repoa.or.tz /documents_storage/Publications/Reports/06.3_Kessy_and_ Urio.pcif

in text citation : (kessy and urion, 2006)

\section{Holy book}

Qur an, $2(25)$

In text citation : (Q. al-Baqarah 2:25).

\section{Encyclopaedia}

Graycar, Adam (1992). Social Welfare Policy. Dalam Mary Hawkesworth dan Maurice Kogan (Ed.), Encyclopedia of Government and Politics (Vol. 1). London: Routledge.

in text citation : (Graycar, 1992)

\section{Interview}

Sultan Hamengkubuwono X (interview, 2011, April 19)

in text citation: (Hamengkubuwono, 2011)

\section{Documentary film}

Steijlen, Fridus (2008). A Day in the Life of Indonesia [documentary film, 58 minutes]. Leiden: KITLV Press.

in text citation : (Steijlen, 2008) 
Vol. 3 No. 1, January - April 2018 